\title{
The First World War and Constitutional Law for the Netherlands Indies
}

\author{
Nick Efthymiou*
}

\begin{abstract}
In the nineteenth and part of the twentieth century, the Kingdom of the Netherlands had colonies both in the West Indies and in the East Indies. This article will focus on the Dutch colonies in the East Indies, i.e., the Netherlands Indies - present-day Indonesia, and will discuss whether the First World War had an impact on the constitutional law for the Netherlands Indies.

This article discusses whether the First World War in any way caused two aspects of constitutional law for the Netherlands Indies: the introduction in May 1918 of the People's Council, a representative body in the Netherlands Indies, and the promises made in November 1918 about the acceleration of constitutional reforms in the Netherlands Indies. The conclusion is reached that the introduction of the People's Council was not caused by the First World War, but that the First World War was a cause for the promises made in November 1918.
\end{abstract}

Keywords: Commission of Inquiry, constitutional law for the Netherlands Indies, Dutch colonial thinking, ethical policy, First World War, November promises, People's Council

\section{Introduction}

In 2007 a bulky standard work was published which dealt with the general impact of the First World War for the Netherlands Indies: Kees van Dijk's The Netherlands Indies and the Great War, 1914-1918. According to Van Dijk, the First World War had important consequences for the colony. The war 'had deeply affected the domestic political situation, had temporarily fundamentally changed the relationship between motherland and colony, and had a great effect on the economic performance of the Netherlands Indies'. ${ }^{1}$

Van Dijk's study primarily focused on political and economic developments in the Netherlands Indies between 1914 and 1918. Less attention was paid to possible consequences of the First World War for constitutional law for the Netherlands Indies, although in his treatment of the political situation Van Dijk also touched on aspects of constitutional law for the Netherlands Indies. In this

* Nick Efthymiou is lecturer at the Erasmus School of Law, Erasmus University of Rotterdam.

1. K. van Dijk, The Netherlands Indies and the Great War, 1914-1918 (2007), at vii. article, two of those touched-on aspects will take centre stage: the establishment in May 1918 of the People's Council (Volksraad), a representative body in the Netherlands Indies, and the promises made in November 1918 about - among other things - the acceleration of constitutional reforms in the Netherlands Indies.

Regarding both aspects, Van Dijk implied that there was a causal connection with the First World War. According to him, both the introduction of the People's Council and the November promises were, at least to a certain extent, caused by the First World War. ${ }^{2}$ This article will examine whether there was indeed a causal connection between the First World War and the introduction of the representative body and between the First World War and the November promises.

To carry out this examination, an outline of some aspects of constitutional law for the Netherlands Indies between 1855 and 1918 must be given. This outline can be found in section 1 of this article. Section 2 of the article will examine whether the First World War in any way caused the introduction of the People's Council. Section 3 of the article will examine whether the First World War in any way caused the November promises.

\section{Constitutional Law for the Netherlands Indies (1855-1918)}

The Netherlands Indies were a colony of the Kingdom of the Netherlands from 1816 until 1942. The latter year brought the de facto ending of the Netherlands Indies, as a consequence of the Japanese occupation of the colony. Attempts to re-establish the colony after the Second World War were in vain.

Constitutional law for the Netherlands Indies during these 126 years can be divided into three periods:

1. The period 1816-1855, with a system that granted all legislative and executive powers to one office, which has been likened to the system of a police state. ${ }^{3}$

2. The period 1855-1925, with a system of separation of powers and checks and balances.

3. The period 1926-1942, with a system of separation of powers and checks and balances that in theory gave

2. Van Dijk, above n. 1, at 285, 399, 593-99.

3. J.H.A. Logemann, 'Over Indië's staatsorde vóór 1854', 78 Mededelingen der koninklijke academie van wetenschappen 3 (1934). 
more powers to offices in the Netherlands Indies than the system of the previous period.

Of these three periods, only the second is of interest for this article.

Constitutional law for the Netherlands Indies had different sources. There were Dutch sources: written law, interpretation of written law by the executive and the judiciary, and unwritten law. And there was an indigenous source: constitutional adat, consisting mainly of unwritten law. ${ }^{4}$ As this article deals with the People's Council and with the November promises insofar as they concerned the powers of the People's Council, and as the People's Council stemmed from Dutch written law, only Dutch sources, especially Dutch written law, will be dealt with in this article.

The People's Council and the November promises are connected with two specific elements of constitutional law, viz. the making of general regulations by the central government level of the Netherlands Indies and the system of checks and balances at this central government level. As a consequence, only these two elements will be dealt with in this article. No mention will therefore be made of the judiciary at the central government level or of offices at decentralised government levels of the Netherlands Indies.

In this paragraph, a sketch will be given of the aforementioned elements of the system of constitutional law of the second period up to 1918. The establishment of the People's Council in 1918, and the question whether this establishment caused changes in the system of the second period as far as the two elements of constitutional law are concerned, will - among other things - be dealt with in the next section.

The main traits of the system of constitutional law for the Netherlands Indies during the period 1855-1925 were found in the Dutch Constitution (Grondwet), as amended in 1848, and in an Act of Parliament, the Government Regulation (Regeringsreglement) of 1854. The Constitution and the Government Regulation created a system of constitutional law for the Netherlands Indies with the following offices at the central government level: the King; the Ministers; the Dutch parliament (also known as the States-General (Staten-Generaal)), consisting of two chambers, the Second Chamber (Tmeede Kamer) and First Chamber (Eerste Kamer); the Governor-General (Gouverneur-Generaal); and the Council of the Netherlands Indies (Raad van Nederlands-Indië).

The first three offices were established in the Netherlands and hardly need further introduction. However, it should be mentioned that the 1848 amendments to the Dutch Constitution introduced political ministerial responsibility of the ministers for all acts of the King. This implied that the King had to perform all his government acts in accordance with one of more Ministers and that criticism by the States-General on any such government act would have to be directed at one or

4. Ph. Kleintjes, Staatsinstellingen van Nederlandsch-Indië (1932), part I, at $1-4$. more of the Ministers, not at the King (who could do no wrong). The introduction of political ministerial responsibility created unity between King and Minister: this unity was (and still is) called the Crown (de Kroon). Political ministerial responsibility also applied to the Netherlands Indies: the Minister of Colonies (Minister van Kolonien) was accountable to the States-General for all government acts and government policies of the Crown concerning this colony. ${ }^{5}$ From 1868 onwards, the rule of confidence applied: should the StatesGeneral not be satisfied with the way the Minister of Colonies gave account, they could force the Minister to tender his resignation to the King.

The fourth and fifth offices were established in the Netherlands Indies and are probably in need of some introduction. The Government Regulation of 1854 stated that the Governor-General is the representative of the King in the Netherlands Indies. The Crown appoints and dismisses him by Royal Decree (Koninklijk Besluit). The Government Regulation of 1854 only stated two requirements to fulfil the function of GovernorGeneral: one had to be a Dutch national and one had to be at least 30 years old. ${ }^{6}$ The Indies government consisted of the Governor-General: he was its only member. He was the highest official in the Netherlands Indies and subordinate to the Crown. As such, he was under control of the Crown and had to obey the orders of the Crown - which were in practice orders of the Minister of Colonies. ${ }^{7}$ Especially since the end of the 1860 s, when telegraph services between the Netherlands and the Netherlands Indies were introduced, the Crown could control the activities of the Governor-General intensely. ${ }^{8}$ According to one author on constitutional law for the Netherlands Indies, the legislative competence of the Governor-General in particular depended 'on the pleasure of the Crown, which has the telegraph at its disposal and can make its will be known in the minutest detail at any moment'. ${ }^{9}$ Of course, the fact that the Governor-General was subordinate to the Crown also implied that the Minister of Colonies was accountable to the States-General for the orders he gave to the Governor-General, and more in general for all government acts of the Governor-General.

The Government Regulation of 1854 stated that the Council of the Netherlands Indies consists of a vicepresident and four members. The vice-president and the members are appointed and dismissed by Royal Decree. To become vice-president or member, one should be a Dutch national and be at least 30 years old. ${ }^{10}$

5. Ph. Kleintjes, Het staatsrecht van Nederlandsch-Indië (1911), part I, at 286-88.

6. Kleintjes (1911), above n. 5, part I, at 297-99; J. de Louter, Handboek van het staats- en administratief recht van Nederlandsch-Indië (1914), at 185-186; Artt. 1-6 Government Regulation of 1854.

7. Articles 20 and 37 Government Regulation of 1854.

8. C. Fasseur, 'Een reuzenstrijder tegen het barbarisme', in C. Fasseur, Indischgasten (1999) 179, at 194.

9. De Louter, above n. 6, at 198-99.

10. Kleintjes (1911), above n. 5, part I, at 334-6; De Louter, above n. 6, at 189-91; Articles 7-12 Government Regulation of 1854. 
The Council of the Netherlands Indies mainly served as an advisory body to the Governor-General.

The five offices were all involved in the making of regulations for the Netherlands Indies. There were three forms of regulation. Firstly, there were Acts of Parliament (metten in formele zin), made by the Crown and the States-General. Secondly, there were Royal Decrees (Koninklijke Besluiten), made by the Crown. Thirdly, there were ordinances (ordonnanties), made by the Governor-General. When making ordinances, the Governor-General of course had to obey the orders of the Crown. He also had to ask the advice of the Council of the Netherlands on the draft ordinance. Should he not agree with the advice of the Council, the matter would normally be handed over to the Crown. The Crown would then make a Royal Decree, without having to take the views of the Governor-General or the Council of the Netherlands Indies into consideration. ${ }^{11}$ The order of regulations just mentioned was also an order of ranking: Acts of Parliament were the highest regulations, followed by Royal Decrees and by ordinances. Once an Act of Parliament had regulated a subject, it was no longer possible to make a Royal Decree or an ordinance on the subject - unless of course the Act provided for the possibility of delegation. This order of ranking notwithstanding, the Dutch Constitution and the Government Regulation of 1854 in essence created an almost completely open system of division of regulatory powers: as a rule, the Constitution and the Government Regulation of 1854 did not prescribe which office had to regulate which subjects. Only a few subjects had to be regulated by an Act of Parliament, for in most subjects regulation by 'general provision' (algemene verordening) was prescribed: a term which included Acts of Parliament, Royal Decrees and ordinances. ${ }^{12}$

In practice, this meant that only very few Acts of Parliament were made for the Netherlands Indies. Most general provisions were either Royal Decrees or ordinances. Having to choose between the latter two, there was a preference for ordinances: about four times as many ordinances were made. This should however not lead to the conclusion that the Governor-General played the leading part in the making of regulations for the Netherlands Indies. In the first place, the most basic regulations, such as the Civil Code for the Netherlands Indies and the Criminal Code for the Netherlands Indies, were made by way of Royal Decree. In the second place, as already mentioned, the Governor-General stood under supervision of the Crown, which in turn stood under supervision of the States-General by means of the political ministerial responsibility and the rule of confidence. ${ }^{13}$ Four of the five offices mentioned were involved in the exercise of executive powers for the Netherlands Indies: the Crown (King and Minister), the Governor-General

11. Articles 59-60 Constitution 1848; Articles 20, 29, 30 and 31 Government Regulation of 1854.

12. Kleintjes (1911), above n. 5, part I, at 218-20; De Louter, above n. 6, at 97-98 and 108-109.

13. N.S. Efthymiou, De organisatie van regelgeving voor Nederlands OostIndië: stelsels en opvattingen (1602-1942) (2005), at 275-78. and the Council of the Netherlands Indies. The Crown held the supreme executive power. ${ }^{14}$ This power implied, among other things, the already mentioned appointment and dismissal by Royal Decree of the Governor-General and the vice-president and members of the Council of the Netherlands Indies.

In the Netherlands Indies, the Governor-General held the executive power. He had to see to the implementation of all general provisions and appoint almost all civil servants in the Netherlands Indies. When exercising this power, he had to ask the advice of the Council of the Netherlands Indies. He was however, with some exceptions, not bound by this advice. In exercising his executive power, the Governor-General of course had to obey all orders of the Crown. Because of this the Crown could supervise the Governor-General, and the StatesGeneral could supervise the Crown in turn. ${ }^{15}$

From the above, it follows that the States-General and the Crown were the central actors, as far as the making of general regulations at the central government level of the Netherlands Indies and the checks and balances at this central government level were concerned. The Governor-General was subordinate to the Crown, and the Council of the Netherlands Indies was hardly anything more than an advisory body. The centre of power lay therefore in the Netherlands.

It is also clear that the indigenous population of the Netherlands Indies played no part in those elements of the constitutional system for the Netherlands Indies that are dealt with in this chapter. All the relevant officeholders were Dutch, and - with the obvious exception of the King - were either appointed by Dutch offices or elected by (part of) the Dutch population in the Netherlands.

\section{The People's Council}

In May 1918, the People's Council convened for the first time. The introduction of this representative body for the Netherlands Indies enabled the indigenous population, also for the first time, to play a part in the making of general regulations and in the system of checks and balances at the central government level - albeit a rather small part.

To understand the reasons for the introduction of the People's Council, and to judge whether the First World War in any way played a part in this introduction, it is necessary to briefly discuss two subjects. Those subjects are the ethical policy (ethische politiek), which was the official Dutch colonial policy from 1901 until at least 1920 , and the plan to introduce a native militia in the Netherlands Indies, i.e. an army of conscripts from the indigenous population in the Netherlands Indies. After the discussion of these two subjects, the People's Coun-

14. Article 59 Constitution 1848

15. Kleintjes (1911), above n. 5, part I, at 324; De Louter, above n. 6, at 203; Articles 27, 28, 43, 44, 49, 50, 52, 53, 55 Government Regulation of 1854 
cil and its origins will be dealt with, and the question whether the First World War played a part in its introduction will be answered.

\subsection{The Ethical Policy}

In the mid nineteenth century, i.e. at the time of the 1848-amendments to the Dutch Constitution and of the genesis of the Government Regulation of 1854, the Dutch government and the States-General adhered to two central assumptions about the relation between the Netherlands and the Netherlands Indies. The first assumption was that the Netherlands Indies were conquered territory that should bring the Netherlands as much profit as possible. The second assumption was that the Netherlands had a duty to provide for the indigenous population of the Netherlands Indies. The duty implied improving both the economic and the mental well-being of this population. It might seem difficult to reconcile the two assumptions, but it had long been thought that profit and well-being could very well be realised simultaneously. ${ }^{16}$

During parliamentary discussions in 1847 about amendments to the Dutch Constitution, for instance, one MP stated that the colonies were a source of affluence for the motherland and that they contained a large indigenous population whose interests should be looked after by the motherland. ${ }^{17}$ More importantly, during the genesis of the Government Regulation of 1854, many MPs and members of government made similar remarks. In the government's memory, in reply, it was stated that the system of the Government Regulation of 1854 should be such that 'subject to the well-being and gradual development of the indigenous population, the Netherlands Indies should continue to provide the motherland the material advantages that are considered to be the purpose of the settlement'. ${ }^{18}$

At the time of the genesis of the Government Regulation of 1854, the question was raised whether the second assumption could imply that the indigenous population should play a part in the government of the Netherlands Indies. This question was answered in the negative: the granting of political rights to the indigenous population was felt to be impossible. One MP stated that the Netherlands Indies were a place 'where government by the people will always remain impossible'. ${ }^{19}$ Another MP stated that the 'indigenous people of those regions are, as is well known, not capable of self-government; they can neither be called upon to take part in the govern-

16. Efthymiou, above n. 13, at 84-86; L. Les, Van Indië onder de compagnie tot Indië onder de staat. De koloniale titel in de Staatsregeling van 1798 (1947), at 101-102; G.J. Schutte, 'Winds of Change: Dutch Colonial Policy during the First Decade of the Nineteenth Century', Papers of the Dutch-Indonesian historical conference held at Noordwijkerhout 1976, at 157; C.H.E. de Wit, De strijd tussen aristocratie en democratie in Nederland 1780-1848. Kritisch onderzoek van een historisch beeld en herwaardering van een periode (1965), at 199-200.

17. Handelingen van de Tweede Kamer der Staten-Generaal (1847-1848), at 746.

18. L.W.C. Keuchenius (ed.), Handelingen der regering en der StatenGeneraal betreffende het reglement op het beleid der regering van Nederlandsch Indië (1857), part II, at 476.

19. Keuchenius, above n. 18, part III, at 1-2. ment nor be allowed to exert any influence on it' ${ }^{20}$ During the general debates in the States-General on the Government Regulation of 1854, the point of view of these MPs was not criticised.

In the course of the second half of the nineteenth century, the second assumption and the aforementioned question became the centre of attention in Dutch colonial thinking. And the answer to the question changed. Gradually the idea took root that the indigenous population should in some way partake in the government of the Netherlands Indies. The well-being of the indigenous people implied, among other things, a role for them in the government of the Netherlands Indies.

An early exponent of the new idea was H.A. des Amorie van der Hoeven, a lawyer and Catholic politician. In 1869 , he expressed the thought that 'the ultimate goal of Dutch rule in the Indies ought to be preparing the Indies for independence'. ${ }^{21}$ This implied educating and civilising the indigenous people, leading to their ability to govern themselves. According to Des Amorie van der Hoeven, the process of educating and civilising was a long-term one: it would take several centuries. ${ }^{22}$ Ten years later, Abraham Kuyper, a theologian, Protestant politician and future Prime Minister, stated that the Netherlands had the moral obligation to look after the Netherlands Indies and its indigenous population. This also implied the obligation to make possible a more independent position for the indigenous population in the future. ${ }^{23}$ In later years, several other authors expressed similar ideas, including a Socialist politician like Van Kol. ${ }^{24}$

Initially, the new idea did not play a central part in Dutch colonial policy. In 1901, when Abraham Kuyper became Prime Minister, the second assumption and the new idea became part of the official Dutch colonial policy, known as the ethical policy. During the first two decades of the twentieth century, all Dutch Cabinets adhered to the principles and assumptions of the ethical policy in colonial matters, irrespective of their political composition.

Concerning the idea of self-government for the Netherlands Indies at the central government level, the ethical policy included four assumptions. Firstly, it was believed that greater independence for the central government officials in the Netherlands Indies was necessary. Secondly, it was felt that this greater independence required the creation of a public body in the Netherlands Indies, which would check the central government officials there, and could possibly play a part in the making of regulations. Such a body should preferably be a representative body, chosen by the population of the Netherlands Indies. Thirdly, it was believed that the

20. Keuchenius, above n. 18, part III, at 60

21. H.A. des Amorie van der Hoeven, Het streven der Indisch-radicalen. Een woord aan Nederlandsche christenen (1869), at 24.

22. Des Amorie van der Hoeven, above n. 21, at 25-26.

23. A. Kuyper, Ons program (1879), at 964

24. H. van Kol, 'Ontwerp-program voor de Nederlandsche koloniale politiek' (Congres S.D.A.P. 1901), 6 De Nieuwe Tijd. Sociaaldemocratisch maandschrift (1901), 199, at 215. 
population of the Netherlands Indies, especially the indigenous population, was not yet ready for the introduction of such a representative body - one with real powers. The population first had to be educated to be able to take part in self-government. Fourthly, it was felt that the education of the indigenous population would take a very long time and should not lead to the termination of the ties between the Netherlands and the Netherlands Indies. ${ }^{25}$

It must be stressed that in 1914, the ethical policy had not yet had any practical consequences for those elements of constitutional law for the Netherlands Indies that are dealt with in this article: representatives of the population of the Netherlands Indies did not play a part in the making of general regulations, nor did they play a part in the system of checks and balances. That would however change in the next few years, although one should not overrate the importance of the change.

\subsection{The Idea of a Native Militia}

The idea of a native militia first occurred in 1907. Between 1907 and 1914, this idea was discussed from time to time, but without any practical results. In 1913-1914, the possibility of such a militia was rejected by the Indies government. ${ }^{26}$ After the outbreak of the First World War, the idea became much more popular, also with the Dutch and Indies government. The need to strengthen the external defence of the Netherlands Indies was now felt more keenly. Though the initial worries that the Netherlands would not be able to remain neutral in the conflict lessened fairly quickly, the native militia would remain 'a hotly debated issue during World War One'. ${ }^{27}$

The issue remained hotly debated because of opposed views about it. On the one hand, the Dutch and Indies government for a long time remained convinced that the external defence of the Netherlands Indies had to be strengthened and that an army of conscripts 'would be a cheaper defence force than an enlarged professional army'. ${ }^{28}$ Also, many members of the Dutch and indigenous population believed that the introduction of a native militia 'would cement interracial solidarity' and would 'encourage discipline, neatness, and personal initiative among the Javanese'. ${ }^{29}$ Thus, the idea of a native militia was connected to elements of the ethical policy: conscription could be useful for the education of the native population. On the other hand, the Indonesian nationalist movement was divided on the issue: part of it was strongly opposed to it, another part supported it. Before clarifying this, a few words must be devoted to this movement. ${ }^{30}$

26. Van Dijk, above n. 1, at 255; M.C. Ricklefs, A history of modern Indonesia since C. 1200 (2008), at 206

27. Van Dijk, above n. 1, at 256

28. Ricklefs, above n. 26, at 206

29. Van Dijk, above n. 1, at 256. Conscription was to be confined to Java and the Minahasa.

30. H. Burgers, De garoeda en de ooievaar. Indonesië van kolonie tot nationale staat (2010), at 168-69; Van Dijk, above n. 1, at 255-56; Ricklefs, above n. 26, at 206-207.
The Indonesian nationalistic movement is generally considered to have started with the establishment of Budi Utomo ('the beautiful endeavour') on 20 May 1908. ${ }^{31}$ This organisation did not however fall from the sky. One cause of its establishment was discomfort about the growing Dutch domination in the Indonesian archipelago in the course of the nineteenth century. This feeling of discomfort had already made itself felt in the third quarter of the nineteenth century, certainly on Java. ${ }^{32}$ Other causes were developments in British India starting at the end of the nineteenth century and the Russo-Japanese War (1904-1905). In British India, the National Indian Congress had been established in 1885 and in the next decades became a national movement asking for Indian self-government. The fact that Japan had beaten Russia in the aforementioned war made (parts of) the indigenous population of the Netherlands Indies realise that European powers were not invincible. Still another cause was that from around 1900 onwards, small parts of the indigenous population of the Netherlands Indies started to receive a western education - one of the consequences of the ethical policy. ${ }^{33}$

The establishment of Budi Utomo was the first overt expression of 'a fundamental transformation of consciousness' of the indigenous population of the Netherlands Indies. ${ }^{34}$ This was also recognised by the Dutch. In a letter of December 1908 to Governor-General Van Heutsz, the colonial civil servant G.A.J. Hazeu wrote that the establishment of Budi Utomo was a sign of changes in the indigenous society: new wishes and new ideals were developing there. ${ }^{35}$

Budi Utomo itself would never play an important part in the nationalist movement. In the early years of the nationalist movement, such a part was reserved for organisations like Sarekat Islam ('Islamic bond'), established around 1910, and the Indies Social Democratic Association (Indische sociaal-democratische vereniging), established in 1914. Sarekat Islam soon became a mass movement, with about 500,000 members in $1915 .{ }^{36}$ Originally not a political movement, in 1916 its leaders started uttering political wishes. The Indies Social Democratic Association was a radical socialist party whose function was 'to unite the Indies socialists (...) and to spread socialist propaganda throughout the

31. R.E. Elson, The Idea of Indonesia. A history (2008), at 10-11; A. Nagazumi, The Origin and the Earlier Years of the Budi Utomo 1908-1918 (1967), at 1; J.M. Pluvier, Overzicht van de ontwikkeling der nationalistische beweging in Indonesië in de jaren 1930 tot 1942 (1953), at 20-21; Ricklefs, above n. 26, at 197.

32. B.R.O'G. Anderson, 'A Time of Darkness and a Time of Light: Transposition in Early Indonesian Nationalist Thought', in: B.R.O'G. Anderson, Language and Power. Exploring Political Cultures in Indonesia (1990), 241, at 241-43.

33. Burgers, above n. 30, at 154-58; H.W. van den Doel, Zo ver de wereld strekt. De geschiedenis van Nederland overzee vanaf 1800 (2011), at 263-65 and 271-72; Nagazumi, above n. 31, at 7-25.

34. Anderson, above n. 32, at 244-45.

35. S.L. van der Wal, De opkomst van de nationalistische beweging in Nederlands-Indië. Een bronnenpublicatie (1967), at 43.

36. A.P.E. Korver, Sarekat Islam 1912-1926. Opkomst, bloei en structuur van Indonesië's eerste massabeweging (1982), at 225 
land'. ${ }^{37}$ The ultimate goals of the Association were the furthering of the international class struggle and national liberation. ${ }^{38}$

Returning to the plan to establish a native militia, this plan divided the nationalist movement. Budi Utomo and some branches of Sarekat Islam were in favour of the plan, at least in 1915 and 1916. Other branches of Sarekat Islam and the Indies Social Democratic Association were against it. Those within the nationalist movement who were in favour took the view 'that the peoples of Indonesia could be expected to defend the colonial regime only if they were represented in its government'. ${ }^{39}$ When the central board of Budi Utomo toured local branches of the organisation in June and July 1915, those branches wanted 'conscription preceded by the establishment of a representative body'. ${ }^{40}$ The same idea - a representative body preceding conscription - was uttered at a Budi Utomo conference in August 1915. In August 1916 Sarekat Islam drafted a resolution that stated 'that the ways to improve the defence of the colony was a matter to be decided on by a Parliament, elected by the people of the Netherlands Indies', although it was admitted 'that it would take time to form such a representative body, and that international developments might make the establishment of a militia a compelling necessity' prior to the establishment of a representative body. ${ }^{41}$ The establishment of a native militia was thus linked to the (prior) establishment of a representative body, in which the indigenous population of the Netherlands Indies could let its voice be heard.

As mentioned, the native militia was an issue for the duration of the First World War. In 1916 supporters of the establishment of a native militia organised a large campaign, known under the name 'Resistant Indies' (Indië meerbaar). In 1917 the organisers of the campaign sent a delegation to the Netherlands to present a resolution to the Dutch government. This resolution did not speak explicitly of a native militia, but did stress the necessity to better the defence of the Netherlands Indies. Earlier, on 12 August 1916, a bill that enabled the introduction of conscription (and thus also of a native militia) in the Netherlands Indies, was introduced into the States-General. The bill was enacted on 23 May 1917. It would not lead to the establishment of a native militia. Once the First World War had finished, the Dutch and Indies governments lost interest. As a result, there was never to be a native militia in the Netherlands Indies. In the meantime, in 1917 and 1918 support within the nationalist movement for a native militia had also evaporated. ${ }^{42}$ The 'hotly debated issue' thus slowly

\footnotetext{
37. R.T. McVey, The rise of Indonesian communism (1965), at 15.

38. McVey, above n. 37, at 30-31

39. Ricklefs, above n. 26 , at 206

40. Van Dijk, above n. 1, at 264

41. Van Dijk, above n. 1, at 265

42. Van Dijk, above n. 1, at 255-86, 469-70, 477, 580; R.C. Kwantes, De ontwikkeling van de nationalistische beweging in Nederlands-Indië. Een bronnenpublicatie (1975-1982), part I, at 94-103.
}

petered out. What remains to be asked is whether it caused the introduction of the People's Council.

\subsection{The People's Council and Its Origins}

Since the end of the nineteenth century, the Dutch government had from time to time developed plans to let inhabitants of the Netherlands Indies become involved in the making of general regulations and in the system of checks and balances at the central government level of the Netherlands Indies. Four of these plans led to bills: a bill introduced by Minister of Colonies Van Dedem in 1893, a bill introduced by Minister of Colonies Fock in 1907, a bill introduced by Minister of Colonies De Waal Malefijt in 1913 and a bill introduced by Minister of Colonies Pleyte in $1915 .^{43}$ Only the last of these bills was to become an Act of Parliament.

The first two bills proposed to add some Dutch inhabitants of the Netherlands Indies to the Council of the Netherlands Indies, and need not concern us here. One thing worth mentioning though is that in 1909, then Minister of Colonies Idenburg, a Protestant politician, stated in a letter to Governor-General Van Heutsz that the bill introduced by Minister Fock was inadequate as it did not provide for the introduction of a representative body. ${ }^{44}$

The third bill is more relevant. It proposed to establish a new office at the central government level of the Netherlands Indies: the Colonial Council (Koloniale Raad). This Council was to have its seat in the Netherlands Indies and to consist of twenty-nine members. Some of these members were to be appointed by the Governor-General; others were to be elected by local councils in the Netherlands Indies - these local councils had been established from 1905 onward. Members of the indigenous population of the Netherlands Indies could be a member of the Colonial Council. The Colonial Council was to play a part in adopting the budget for the Netherlands Indies, but not in the making of ordinances. ${ }^{45}$

In his explanatory memorandum, Minister De Waal Malefijt stated that the introduction of a Colonial Council was necessary for a better promotion of the interests of the indigenous population of the Netherlands Indies. The Colonial Council could therefore be described as a representative body. It was however too early to let this body play a part in the making of regulations for the Netherlands Indies. For this to be possible, further education of the indigenous population was still necessary. ${ }^{46}$ It seems clear that the bill and the explanatory memorandum fitted in well with the second and third assumptions of the ethical policy concerning self-government, as described in section 2.1 of this article.

43. For the text of the bills, see respectively Bijlagen bij de Handelingen van de Tweede Kamer der Staten-Generaal, 1893-1894, 104, 2; 1906-1907, 180, 3; 1912-1913，344，2；1914-1915，365, 2. Van Dedem was a Liberal politician, as were Fock and Pleyte, De Waal Malefijt was a Protestant politician.

44. S.L. van der Wal, De Volksraad en de staatkundige ontwikkeling van Nederlands-Indië. Een bronnenpublicatie (1964-1965), part I, at 109

45. Bijlagen (1912-1913), above n. 43, 344, 2.

46. Bijlagen (1912-1913), above n. 43, 344, 4, at 7 
The next Minister of Colonies, Pleyte, agreed with De Waal Malefijt that the introduction of a representative body in the Netherlands Indies was necessary for a better promotion of the interests of the indigenous population of the Netherlands Indies. Pleyte however had other ideas about the composition and powers of such a body - as will be described below. ${ }^{47}$ On 21 May 1915, he therefore introduced his own bill. The bill was enacted on 16 December 1916 and led to the establishment of the People's Council on 18 May 1918. The main regulations about the People's Council were placed in a new chapter of the Government Regulation of 1854: chapter ten, consisting of Articles 131-144.

The People's Council had its seat in Batavia, the capital of the Netherlands Indies. Originally it had thirtynine members; from 1920 onwards, it had fortynine members. ${ }^{48}$ To become a member, one had to be a male inhabitant of the Netherlands Indies, and at least 25 years old. The member that was also chairman was appointed by Royal Decree. Of the other members, the Governor-General appointed half and local councils in the Netherlands Indies elected half. Approximately forty percent of the members of the People's Council belonged to the indigenous population of the Netherlands Indies. ${ }^{49}$

The People's Council was an advisory body for the Governor-General. According to Article 131 of the Government Regulation of 1854, the Governor-General was entitled, and in some cases obliged to ask the advice of the People's Council. Concerning general provisions, the Governor-General was obliged to ask the advice of the People's Council if these provisions implied personal military burdens for the inhabitants of the Netherlands Indies. The Governor-General was never bound by an advice of the People's Council. ${ }^{50}$ Nor was the Governor-General in any way responsible to the People's Council; he remained as before subordinate to the Crown, who supervised him.

It should be clear that the People's Council was not given any real constitutional powers. The system of constitutional law for the Netherlands Indies of the period 1855-1925, and more specifically the two elements of constitutional law in that period dealt with in this article, were not fundamentally changed by its introduction. Changes in those elements would only occur in 1926, at the beginning of the third period of constitutional law for the Netherlands Indies. In this third period, the People's Council was to have more influence, especially as regards the making of general regulations - though it was still not to have any decisive influence. A further discussion of this third period is however outside the scope of this article.

47. Bijlagen (1914-1915), above n. 43, 365, 3; Van der Wal (1964-1965), above n. 44 , part I, at 149 .

48. In 1925, the number of members increased further to sixty-one members.

49. Ph. Kleintjes, Staatsinstellingen van Nederlandsch-Indië (1923), part I, at 192-95; Arts. 132, 133 and 139 Government Regulation of 1854.

50. Kleintjes (1923), above n. 49, part I, at 209-13.
In the years leading up to 1926 , the main function of the People's Council was the better public promotion of the interests of the indigenous population of the Netherlands Indies. Because of this function, the People's Council could be called a representative body. It was however hardly representative in the sense that the indigenous population played an important part in the election of its members. As mentioned, only half of its members were chosen, namely, by members of local councils. This electorate consisted of very few people: 1,127 male persons in 1923. Some members of the electorate were appointed by the Governor-General, others were ex-officio members, and still other members were chosen by a small number of people, viz. those men who were at least 23 years old, were a resident within the jurisdiction of one of the local councils, and had a yearly income of at least $f 600$ (if they belonged to the indigenous population) or $f 900$ (if they were Dutch). ${ }^{51}$

At first sight, the establishment of the People's Council could be considered to follow from the assumptions of the ethical policy. It was a representative body, as the second assumption required, but without any real pow$\mathrm{er}$, as the third assumption required. The indigenous population was not yet ready for a representative body with real powers and had to be educated to be able to partake in self-government, as the third assumption stated. The People's Council could be seen as a means to educate the indigenous population and thus be linked to the ethical policy. Should this be true, then the ethical policy would be the cause for the establishment of the People's Council.

Some writers however have claimed that there is a close connection between the campaign for a native militia and the reaction of the nationalist movement to this campaign on the one hand, and the establishment of the People's Council on the other hand. According to Van Dijk for instance, the 'discussion about a native militia had one important result. A quasi-representative body was founded. The demands of the nationalist organisations may well have speeded this up' ${ }^{52}$ At places, Van Dijk seems even more certain of a connection between the campaign for a native militia and the introduction of the People's Council. Thus, he states: 'In exchange for Indonesian support for the establishment of [a] native militia, the Netherlands Indies was (...) to be given a People's Council'. ${ }^{53}$ Should there be such a connection, then this would lead one to conclude that the First World War was a - perhaps somewhat indirect - cause for the establishment of the People's Council. It had after all been the outbreak of the First World War that had made the establishment of a native militia a much debated issue.

To assess which of the two causes is the more likely one, the parliamentary debate on Pleyte's bill needs to be dis-

51. Kleintjes (1923), above n. 49, part II, at 59-62; Verslag van de commissie tot bestudeering van staatsrechtelijke hervormingen, ingesteld bij gouvernementsbesluit van 14 september 1940 (1944), part I, at 93.

52. Van Dijk, above n. 1, at 285. For similar remarks see Elson, above n. 31, at 19-20 and Ricklefs, above n. 26, at 194 and 206.

53. Van Dijk, above, n. 1, at 399. 
cussed. As already mentioned, both De Waal Malefijt and Pleyte wanted to establish a representative body in the Netherlands Indies so that the interests of the indigenous population in the Netherlands Indies could be better promoted. Pleyte however had other ideas about the composition and powers of such a body, as he stated in a letter to then Governor-General Idenburg of 22 January 1915 and in the explanatory memorandum to his own bill. ${ }^{54}$

De Waal Malefijt had felt that a large part of the members of a Colonial Council should consist of civil servants. He believed that civil servants were aware of the needs of the indigenous population and could represent its interests. Pleyte on the other hand did not believe that such an awareness was limited to civil servants. He therefore felt no need for a separate contingent of civil servants in the representative body. The inhabitants of the Netherlands Indies, including the indigenous population, should be given ample opportunity to delegate representatives of their interests..$^{55}$

Concerning the powers of the representative body, Pleyte - as already shown - felt that it also could play a small part in the making of ordinances: the GovernorGeneral ought to be able to ask the advice of the representative body. More importantly still, Pleyte believed that the representative body could be given greater powers in the future. In his explanatory memorandum, he stated that 'as the suitability of the indigenous population to partake in the government policy grew intellectually and economically, the representative body could get a greater influence on the course of events'. ${ }^{56}$ Pleyte also believed that regular contact between the government in the Netherlands Indies and the representative body would prepare this body 'for a future task which would both be broader and deeper'. ${ }^{57}$ Later, in his response of 19 October 1915 to the preliminary report of the Second Chamber of the States-General, Pleyte emphasised that at present the representative body was not to be given any decisive influence on the GovernorGeneral: for now, its task 'was to remain purely advisory'. ${ }^{58}$

In the preliminary report of the Second Chamber of the States-General of 31 August 1915 on Pleyte's bill, many members of the Second Chamber welcomed the bill. They believed that the population of the Netherlands Indies should be given some possibility to participate in the administration of the colony. They also believed that the introduction of a representative body would strengthen the ties between the indigenous population and the Dutch authorities. Finally, and perhaps most importantly, they believed that 'the introduction of a representative body would promote the political education of the population'. ${ }^{59}$

54. Bijlagen (1914-1915), above n. 43, 365, 3; Van der Wal (1964-1965), above n. 44, part I, at 149

55. Bijlagen (1914-1915), above n. 43, 365, 3, at 3-4

56. Bijlagen (1914-1915), above n. 43, 365, 3, at 5

57. Bijlagen (1914-1915), above n. 43, 365, 3, at 5

58. Bijlagen (1915-1916), above n. 43, 54 and 45, 1, at 2 .

59. Bijlagen (1914-1915), above n. 43, 365 and 61, 4, at 9.
During the oral deliberations about Pleyte's bill in the Second Chamber, held in September and October 1916, several MPs made more or less similar remarks about the introduction of a representative body. The Protestant MP Beumer was happy with the introduction. If one strived for a Netherlands Indies inhabited by a population which is animated with feelings of affection towards the motherland, which has reached higher spiritual and material prosperity and is able to fulfil the requirements demanded by the full development of the principles of autonomy and self-government, then one should take those measures that can lead to realisation of this ideal'. ${ }^{60}$ The introduction of a representative body was such a measure and therefore, according to Beumer, 'an act of prudence'. ${ }^{61}$ The Liberal MP Knobel thought the introduction was 'an appropriate experiment' and 'a measure of political education'. ${ }^{62}$ According to the Catholic MP Bogaardt, the indigenous population should be lifted up 'morally, materially and politically to a western level', and Pleyte's bill was 'the first step on a long road of representation, that should lead to autonomy with self-government'. ${ }^{63}$ The Liberal MP and former Minister of Colonies Fock stressed that the introduction would be 'educative' ${ }^{64}$ Finally, Minister Pleyte, in his reaction to the speeches of various MPs, underscored that the bill was meant as 'a first step on the road leading to the granting of legislative power to the Netherlands Indies'. ${ }^{65}$ The powers that were granted to the representative body in the bill were, according to Pleyte, 'nothing more than an expedient, a surrogate'. ${ }^{66}$ For the time being only this surrogate could be granted because, again according to Pleyte, 'a large majority of the population was not ready' for choosing a representative body with greater powers. ${ }^{67}$

During the parliamentary debate on Pleyte's bill, the native militia and the 'Resistant Indies' campaign were also mentioned occasionally. The first remarks on these two subjects were made by MP Knobel. According to him, as Pleyte's bill gave the (native) population of the Netherlands Indies more political rights, it was only natural that something in return was asked of this population. Knobel believed that if rights are given, 'one should perform duties in return'; these 'duties' referred especially to the introduction of a native militia: natives 'should be armed to defend the Netherlands Indies' ${ }^{68}$ Other MPs opposed Knobel's observations. The Social Democratic MP Mendels stressed that the representative body and the 'Resistant Indies' campaign were two completely different subjects. There was 'no legal basis and no moral ground' to connect the two. ${ }^{69}$ In reply to

60. Handelingen van de Tweede Kamer der Staten-Generaal, 1916-1917, at 20.

61. Handelingen (1916-1917), above n. 60, at 21

62. Handelingen (1916-1917), above n. 60, at 29

63. Handelingen (1916-1917), above n. 60, at 36

64. Handelingen (1916-1917), above n. 60, at 45

65. Handelingen (1916-1917), above n. 60, at 47

66. Handelingen (1916-1917), above n. 60, at 54

67. Handelingen (1916-1917), above n. 60, at 54

68. Handelingen (1916-1917), above n. 60, at 32

69. Handelingen (1916-1917), above n. 60, at 38. 
Knobel's remark that the matter of the 'Resistant Indies' campaign had been discussed in the parliamentary documents on the representative body, Mendels stated that one 'would need a magnifying glass to find out whether this matter had been discussed in these documents'. ${ }^{70}$ Fock emphasised that the introduction of an official body in the Netherlands Indies, of which nonofficial persons would be members, had 'first been brought up almost twenty-five years ago', i.e. at a time when 'no-one had raised the matter of a native militia' ${ }^{71}$ He added that when Pleyte's bill was introduced in May 1915 , 'there were no plans for the imposition of a militia duty'. ${ }^{72}$ Finally, Beumer felt that there was 'no connection between an opinion on proposals for a native militia and an opinion on the introduction of a representative body'. ${ }^{73}$

The preceding account of the debate on Pleyte's bill shows that Pleyte and several MPs connected the establishment of the People's Council with the ethical policy. The stress on the educative character of the People's Council, on the fact that this body could not yet be given any real powers and on the fact that the introduction of the People's Council was seen as the first step on a long road leading to the granting of legislative power to the Netherlands Indies: all this fitted in well with the aforementioned assumptions of the ethical policy concerning self-government.

The account of the debate also shows that discussions about the native militia and the 'Resistant Indies' campaign seem an unlikely cause for the establishment of the People's Council. MP's Mendels, Fock and Beumer could not see any connection between the People's Council and the native militia or the 'Resistant Indies' campaign. They certainly did not think that discussions on the native militia or the 'Resistant Indies' campaign were a cause for the establishment of the People's Council. And perhaps not even MP Knobel thought this. He did not claim that the discussions on the native militia campaign caused the introduction of the People's Council. He merely reasoned that the establishment of the People's Council made it easier to defend the introduction of a native militia - which is not the same thing as claiming that the native militia discussion caused the establishment of the People's Council. Knobel's remarks during the debate could be interpreted as a claim that the establishment of the People's Council could become the cause of the introduction of a native militia. Furthermore, the observations of MP's Fock and Mendels make sense. The People's Council had had a long history that predated the discussions on the native militia, and nowhere in Pleyte's bill and explanatory memorandum had a connection been made between the native militia and the People's Council.

There are more arguments against the view that there was a connection between discussions on the native

70. Handelingen (1916-1917), above n. 60, at 38 .

71. Handelingen (1916-1917), above n. 60, at 43-44.

72. Handelingen (1916-1917), above n. 60, at 44

73. Handelingen (1916-1917), above n. 60, at 57 militia and the establishment of the People's Council. Firstly, when in March 1917 the aforementioned bill that made the introduction of conscription (and thus also of a native militia) in the Netherlands Indies possible was discussed in the States-General, again no-one explicitly claimed that the discussions on the native militia were a cause for the introduction of the People's Council. At best it can be said that the Catholic MP Nolens more or less repeated Knobel's reasoning. Nolens said that the introduction of the People's Council amounted to granting political rights. The introduction 'was the beginning of a complete reversal in the administration of the Netherlands Indies which could be accompanied by the imposition of militia duty'. ${ }^{74}$

Secondly, correspondence on the establishment of a representative body in the Netherlands Indies between Minister Pleyte and then Governor-General Idenburg in February and March 1915 - just before the introduction of Pleyte's bill - confirms the remarks made by MP Fock during the parliamentary debate on Pleyte's bill. Neither Pleyte nor Idenburg connected such an establishment with the defence of the Netherlands Indies. Idenburg especially stressed that the establishment of a representative body had been a long-term project. In his letter of 24 February 1915 to Pleyte, he expressed the hope that Pleyte would succeed in introducing a representative body: 'the matter has been worked on long enough, now should be the time to harvest'. ${ }^{75}$ And in his letter of 31 March 1915 to Pleyte, Idenburg stressed that 'the matter, which is of great importance, has been pending for a very long time'. ${ }^{76}$

All in all, a link between discussions on a native militia and the establishment of the People's Council does not seem very likely. It might be added that it also seems unlikely that, as Van Dijk tentatively states, demands of nationalist organisations speeded up the introduction of the People's Council. Some occurrences during the parliamentary debates on Pleyte's bill on the People's Council can illustrate this. On 20 July 1916, more than a year after Pleyte's bill on the People's Council had been introduced, MP Knobel proposed to speed up the consideration of the bill because of 'its great urgency' and because of a request of Sarekat Islam made on 3 July 1916 for 'a speedy consideration of the bill' ${ }^{77}$ Knobel wanted a parliamentary debate on the bill at the end of July or the beginning of August. A majority of the Second Chamber of the States-General opposed the proposal. According to one MP, the Social Democrat Schaper, Pleyte's bill was 'as urgent as dozens of other bills'. ${ }^{78}$ A week later Knobel withdrew his proposal. ${ }^{79}$ Following this, Pleyte informed Governor-General Van Limburg Stirum in a telegram of 28 July 1916 that because of another 'law proposal (...) of utmost urgency

74. Handelingen (1916-1917), above n. 60, at 2250

75. Van der Wal (1964-1965), above n. 44, part I, at 152.

76. Van der Wal (1964-1965), above n. 44, part I, at 155.

77. Handelingen (1916-1917), above n. 60, at 2557. Sarekat Islam had not explicitly connected its request with the introduction of a native militia.

78. Handelingen (1916-1917), above n. 60, at 2557.

79. Handelingen (1916-1917), above n. 60, at 2561. 
(...) before September reading colonial bill cannot be expected' ${ }^{80}$ As a consequence, the debate in the Second Chamber on Pleyte's bill was only held at the end of September 1916 and the beginning of October 1916.

In conclusion, it can be said that there are no real indications that the People's Council was established as a result of discussions on a native militia or that the establishment was speeded up by these discussions or by demands of nationalist organisations. The discussions on the native militia and by extension the First World War, seem to have played no significant part in the establishment of the People's Council. It seems much more likely that this establishment was a result of the ethical policy.

\section{The November Promises}

In November 1918, promises on behalf of the Governor-General were made in the People's Council. These promises concerned - among other things - the acceleration of constitutional reforms in the Netherlands Indies. One important consequence of the promises was the establishment of a Commission of Inquiry in December 1918. This Commission was to advise the Governor-General on the desirability of changes to the fundamental features of the form of government of the Netherlands Indies.

To examine whether the First World War in any way caused the November promises and the establishment of the Commission of Inquiry, some developments before November 1918 must be described. After this description, the November promises and the establishment of the Commission of Inquiry will be dealt with, and the question whether the First World War played a part in them will be answered.

\subsection{Previous History}

To understand the meaning and the causes of the promises of November 1918, it is necessary to point out some earlier developments. Firstly, by the end of 1916 the First World War had made communication between the Netherlands and the Netherlands Indies difficult - a situation that would remain so until the end of the First World War. This had consequences for the contacts between the Indies government and the Minister of Colonies. As Van Dijk states, consultation 'with the Ministry of the Colonies in The Hague had become almost impossible. The mail and telegraph communications between the Netherlands Indies and Holland either hardly functioned or did not exist at all. Communication between the Ministry and the Governor General by mail could take weeks, if not months, to reach its desti-

80. Van der Wal (1964-1965), above n. 44, part I, at 183-184. The telegram was in English. Great Britain controlled cable traffic and telegrams had to be written in English because they had to pass the British censor: Van Dijk, above n. 1, at 201; Handelingen (1918-1919), above n. 60, at 2085. Van Limburg Stirum was Governor-General from March 21 , 1916 until March 21, 1921 and the originator of the November promises. nation, communication by telegram was also disrupted from time to time. ${ }^{81}$ According to Van Dijk, this 'provided the colony with some political independence'. ${ }^{82}$ Secondly, the faulty communication certainly caused the Governor-General to plead for changes in the relation between the Netherlands and the Netherlands Indies. In a letter of 6 April 1917 to Minister Pleyte, Governor-General Van Limburg Stirum wrote that 'Holland will have to realise that the lead in Indian affairs should pass from there to here. The present faulty communication has caused Holland to be only very imperfectly informed, the constant profound contact by weekly letters is broken. The Netherlands Indies fara da se in many ways. ${ }^{93}$ These ways included politics. According to Van Limburg Stirum in the same letter, 'the situation in which every important measure requires a decision of the Dutch government will have to be changed, as this situation is outdated and will become more and more vexing'. ${ }^{84}$ In a telegram of 16 April 1918 to Minister Pleyte, Van Limburg Stirum more or less said the same: 'I again repeat war which forced India in many respects to help itself has created strong fara da se feeling which it is imperative for government not to ignore'. ${ }^{85}$

Thirdly, when Governor-General Van Limburg Stirum made a speech in the People's Council on 18 May 1918, on the occasion of its installation, he said that the establishment of the People's Council was an important step on the way to 'a responsible government in the Netherlands Indies that, in collaboration with the People's Council, will be empowered to make final decisions on all matters that are not imperial. We should proceed to the goal of a responsible government as fast as is appropriate'. ${ }^{86}$ In the aforementioned telegram of 16 April 1918 to Minister Pleyte, Van Limburg Stirum had discussed the general trend of his speech, including the idea of a responsible government and its powers. In his telegram of 1 May 1918 to Governor-General Van Limburg Stirum, Pleyte said that he heartily agreed with the 'trend [of the] opening speech'. ${ }^{87}$ It is important to notice Minister Pleyte's agreement, since it shows that that there had been consultation between the Minister and the Governor-General on the opening speech. It is also important to notice that the words 'as fast as is appropriate' were sufficiently vague, so as not to create unrealistic expectations.

As will be shown in the next paragraph, when the November promises were made, they went a step further in comparison with the speech of 18 May 1918. Those promises were more in line with the fara da se

81. Van Dijk, above n. 1, at $x$

82. Van Dijk, above n. 1, at $\mathrm{x}$

83. Van der Wal (1964-1965), above n. 44, part I, at 190-91

84. Van der Wal (1964-1965), above n. 44, part I, at 191.

85. Van der Wal (1964-1965), above n. 44, part I, at 226. The telegram was in English. 'India' refers to the Netherlands Indies.

86. Handelingen van de Volksraad, 1e gewone zitting, 1918, at 1-2. 'Imperial' refers to those matters that concerned both the Netherlands Indies and the Netherlands.

87. Van der Wal (1964-1965), above n. 44, part I, at 226. The telegram was in English. 
feeling Governor-General Van Limburg Stirum had expressed on earlier occasions.

\subsection{The November Promises and the}

Establishment of the Commission of Inquiry There is a link between the promises of November 1918 and occurrences in Europe that same month. In the beginning of November 1918, just before the end of the First World War, a revolution broke out in Germany. The revolution was - among other things - caused by the heavy burdens imposed upon the country by the war and by the upcoming German defeat. The revolution brought an end to the German Empire and made Germany a republic. On 11 November 1918, MP Troelstra, the parliamentary leader of the Dutch Social Democratic Workers Party (Sociaal-democratische arbeiderspartij), gave a speech in Rotterdam. In this speech he claimed, influenced by the events in Germany, that the workers in the Netherlands were ready to seize power. The next day, he said more or less the same in Dutch parliament. After being heavily criticised, he backed out and said that he had been misunderstood. The threat of revolution in the Netherlands thus proved to be a storm in a teacup. ${ }^{88}$

On 15 November 1918, Minister of Colonies Idenburg sent a telegram about the recent developments to Governor-General Van Limburg. The telegram stated that there had been 'Widespread nervousness caused by Troelstra speeches socialist meeting Rotterdam repeated Tuesday in chamber urging immediate transfer Government to socialists following German example', but concluded with the following remark: 'Yesterday nervousness considerably allayed. Troelstra declared no intention use violence'. ${ }^{89}$

When news about the revolution in Germany and Troelstra's remarks became known in the Netherlands Indies in November 1918, they caused (political) unrest there. In a letter of 1 December 1918 to Idenburg, Van Limburg Stirum reported that the developments in Europe had caused 'a strong red wind in the Netherlands Indies', and 'demands for a [Western style] parliament there' had 'impressed people and made them very nervous' and had caused 'wild rumours about an abdication of the Queen and my replacement'. ${ }^{90}$ In the same letter, Van Limburg Stirum mentioned that on 16 November 1918, the unrest in the Netherlands Indies made him decide to have a statement read on his behalf in the People's Council 'to show that the Indies government was not blind to the signs of the times'. ${ }^{91}$

To calm things down, on 17 November 1918, the Governor-General made public the content of Idenburg's telegram of November 15. Then on 18 November 1918, a senior civil servant made the aforementioned state-

88. J.Th.J. van den Berg and J.J. Vis, De eerste honderdvijftig jaar. Parlementaire geschiedenis van Nederland 1796-1946 (2013), at 585-589; P.J. Oud, Het jongste verleden. Parlementaire geschiedenis van Nederland 1918-1940 (1968), part I, at 78-105

89. Van der Wal (1964-1965), above n. 44, part I, at 254. The telegram was in English.

90. Van der Wal (1964-1965), above n. 44, part I, at 257.

91. Van der Wal (1964-1965), above n. 44, part I, at 257. ment on behalf of the Governor-General in the People's Council. This statement contained several promises - the November promises. Most important for the purposes of this article was the promise of accelerated constitutional reforms. According to the statement, the new direction 'which the youngest earth-shaking affairs have prescribed for the Netherlands, also laid down the course which has to be followed here. This is however less a change in course than an acceleration of pace. The Indies government and the People's Council as a consequence will be confronted with new relationships and shifts in powers, which are unforeseeable at this time. One thing though is certain: both offices will have more duties to fulfil and will have to cooperate more closely. ${ }^{, 92}$

The promise of constitutional reform was in itself nothing new. The speech of 18 May 1918 had also promised such reforms. But whereas the speech had talked about reforms 'as fast as is appropriate', the statement talked about 'an acceleration of pace'. These latter words caused a stir in the People's Council. In the report of the People's Council of 23 November 1918, some members felt that the statement implied that a parliamentary system and democracy would soon be introduced in the Netherlands Indies. ${ }^{93}$ In an address of response of 25 November 1918, the People's Council asked for a clarification of the statement of 18 November $1918 .{ }^{94}$ This clarification was given on 2 December 1918, when a new statement was made in the People's Council by a senior civil servant on behalf of the Governor-General.

In this statement, it was said once again that 'farreaching reforms were necessary $(. .$.$) at a faster pace',$ but at the same time it was added that 'in such reforms, caution is urgently needed' and that when reforming 'the actual circumstances and the prevailing conditions in the Netherlands Indies should be taken into account'. ${ }^{95}$ By combining promises of far-reaching reforms with the notion of caution and with attention to circumstances and conditions, the statement of 2 December 1918 became rather non-committal and open to several interpretations.

One part of the statement was certainly not noncommittal: it announced the establishment of a commission of inquiry 'to advise the Indies government on proposals to the Dutch government about the desirability of a revision of the foundations of the constitution of the Netherlands Indies'. ${ }^{96}$ Governor-General Van Limburg Stirum had decided to establish such a commission in November 1918 and had informed Minister Idenburg of his decision in a telegram of 28 November $1918 .{ }^{97}$ Following the statement, on 17 December 1918, GovernorGeneral Van Limburg Stirum created a 'Commission of Inquiry into the reviewing of the form of government of

92. Handelingen van de Volksraad, tweede gewone zitting (1918-1919), at 251.

93. Bijlagen bij de Handelingen van de Volksraad (1918-1919), 27, 1, at 1.

94. Handelingen, above n. 92, at 284.

95. Handelingen, above n. 92, at 429-30

96. Handelingen, above n. 92, at 430.

97. Van der Wal (1964-1965), above n. 44, part I, at 255. 
the Netherlands Indies' (Commissie tot herziening van de staatsinrichting van Nederlandsch-Indië). The Commission was officially installed on 28 December 1918.

The Commission of Inquiry consisted of some thirty members. Some members were Dutch, other members were from the indigenous population. The Commission was chaired by the President of the Supreme Court of the Netherlands Indies - he later became a member of the Council of the Netherlands Indies - professor Carpentier Alting. ${ }^{98}$ The Commission of Inquiry was to advise the Governor-General on the desirability of changes to the fundamental features of the form of government of the Netherlands Indies.

In order to better fulfil its function, the Commission of Inquiry split into three subcommittees, although there were also regular plenary sessions. The work of the Commission resulted in a report of over 600 pages that was presented to Governor-General Van Limburg Stirum on 30 June 1920. The report contained a general explanation on the desirability of changes in the form of government of the Netherlands Indies, a draft constitution for the Netherlands Indies and ten minority notes - not all members of the Commission agreed on all the elements of the general explanation and the draft constitution, which had been adopted by majority decision. ${ }^{99}$ The report of the Commission was widely discussed. It did not however become the foundation of the new system of constitutional law for the Netherlands Indies that was constituted in 1926. ${ }^{100}$

Analysing the November promises and the establishment of the Commission of Inquiry, it must be stressed that Governor-General Van Limburg Stirum had not conferred about them with Minister Idenburg. It seems therefore possible that in November 1918, the 'fara da se' feeling in the Netherlands Indies, which he had described in his aforementioned letters to Minister Pleyte, had influenced the Governor-General. The promises and the establishment of the Commission were important policy decisions, which ought to have been discussed beforehand with the Minister of Colonies.

Minister Idenburg certainly was not amused. In a letter of 11 December 1918 to Van Limburg Stirum, he wrote that the developments in Europe had had an 'unnecessarily large influence' in the Netherlands Indies and that 'in the Indies we should not sway to the issues of the day'. ${ }^{101}$ The Netherlands Indies were not ready for democracy, and its introduction would lead to abuses. Concerning the creation of the Commission of Inquiry, Idenburg wrote that his first impression was that it would have been better to create such a commission in the Netherlands', but that on second thought he understood that 'your commission was meant as a lightning rod and as such not only had disadvantages, but also

98. Verslag van de commissie tot herziening van de staatsinrichting van Nederlandsch-Indië, ingesteld bij gouvernementsbes/uit van den 17en december 1918, No. 1 (1920), at XI-XII.

99. Verslag, above n. 98 , at XVI-XIX.

100. Kleintjes (1932), above n. 4, part I, at 24-30.

101. Van der Wal (1964-1965), above n. 44, part I, at 261. advantages'. ${ }^{102}$ And in a letter of 6 February 1919 to Van Limburg Stirum, Idenburg wrote that the statements of 18 November 1918 and 2 December 1918 were in itself understandable, but had unfortunately 'created the impression that the Indies government and the Dutch government had come to an agreement about all sorts of very far-reaching political reforms'. ${ }^{103}$ Finally, in a letter of 8 February 1919 to Van Limburg Stirum, Idenburg wrote that 'the making of far-reaching statements without the explicit authorisation of the Dutch government would under normal circumstances have been unthinkable'. The special circumstances of November 1918 were a mitigating circumstance, but 'it was very regrettable that the statements (...) had not contained an explicit reservation regarding the approval of the Dutch government and the States-General'. The statements should also have mentioned that 'the Dutch government and the States-General had been completely ignorant of the promised radical changes' ${ }^{104}$

As a result of these letters, Governor-General Van Limburg Stirum felt the need to reconfirm his subordination to the Minister. In a letter of 20 December 1918 to Minister Idenburg, he fully acknowledged that he 'was sent to the Netherlands Indies to govern regardless of his own wishes' ${ }^{105}$ And in a letter of 2 April 1919 to Minister Idenburg he acknowledged that, having reread the Proceedings of the People's Council, 'for some members of the People's Council it was not unequivocally clear that the Dutch government had not been consulted and that it would have been more correct to declare explicitly that the Dutch government had not been consulted'. ${ }^{106}$ The Governor-General also felt the need to stress that he did not support radical reforms. In a letter of 14 May 1919 to Minister Idenburg, he wrote that he believed that the introduction in the Netherlands Indies of a western style parliament with real powers for the time being was 'impossible'. ${ }^{107}$

In the course of 1919, Minister Idenburg's tone became more conciliatory. The content of the letters of the Governor-General and especially the realisation that the statement of 2 December 1918 was non-committal and open to several interpretations, in all likelihood caused this. In a letter of 12 May 1919 to Governor-General Van Limburg Stirum, the Minister wrote that there was 'not a principal, but only a practical difference of opinion' between the Governor-General and the Minister. Neither of them advocated the 'immediate introduction of responsible government' in the Netherlands Indies - i.e. the immediate introduction of a western style parliament and of a parliamentary system. ${ }^{108}$ And in parliamentary debates about the November promises, Minister Idenburg defended the actions of the Governor-General.

102. Van der Wal (1964-1965), above n. 44, part I, at 262

103. Van der Wal (1964-1965), above n. 44, part I, at 291.

104. Van der Wal (1964-1965), above n. 44, part I, at 295.

105. Van der Wal (1964-1965), above n. 44, part I, at 263.

106. Van der Wal (1964-1965), above n. 44, part I, at 318.

107. Van der Wal (1964-1965), above n. 44, part I, at 329.

108. Van der Wal (1964-1965), above n. 44, part I, at 323. 
On 8 April 1919 during the debate in the Second Chamber, the Minister quoted that part of the statement of 2 December 1918 that read that when reforming, the actual circumstances and the prevailing conditions in the Netherlands Indies should be taken into account. To his quote he added that the Governor-General understood that the Netherlands Indies needed 'cautious policy'. ${ }^{109}$ On 5 June 1919 during the debate in the First Chamber, the Minister was more explicit in his defence of the Governor-General. Talking about the statements of 18 November 1918 and 2 December 1918, he said that although some expressions in the statements might have been worded differently, 'regarding the substance of the matter (...) there is no difference of opinion between the Governor-General and me. (...) We are in total agreement about this substance'. ${ }^{110}$ Both Chambers accepted the Minister's defence of the GovernorGeneral's actions and the Minister's interpretation of the November promises.

In conclusion, it can be said that the November promises and the establishment of the Commission of Inquiry probably are linked to the First World War. The fara da se mentality that had developed in the Netherlands Indies because of the First World War seems to have influenced the Governor-General when he decided to make the November promises and to establish the Commission of Inquiry. Furthermore, the events in Germany and the Netherlands in November 1918, which were linked to the First World War, seem to have triggered the November promises and the establishment of the Commission of Inquiry.

After some months, when the situation in the Netherlands and in the Netherlands Indies had calmed down, the somewhat assertive mood of the Governor-General, shown in his fara da se remarks and his actions in November 1918, died down. He became aware once again of his subordination to the Minister, and as a result possible differences between the GovernorGeneral and the Minister were played down and ironed out. This happened both in the correspondence between the two men and during the parliamentary debates of 1919. The 'normal' hierarchical relationship between the Minister and the Governor-General was thereby restored. The November promises and the establishment of the Commission of Inquiry did not cause a lasting change in the hierarchy between Minister Idenburg and Governor-General Van Limburg Stirum.

\section{Conclusion}

After the above, this section can be brief. At the beginning of this article, it was mentioned that according to Van Dijk both the introduction of the People's Council and the November promises were, at least to a certain extent, caused by the First World War. Van Dijk's view seems only partly correct. Having discussed the introduction of the People's Council, it seems unlikely that the First World War played any significant part in it. The People's Council in all likelihood stemmed from the ethical policy and was the result of a rather lengthy process that had begun in the last decade of the nineteenth century.

The First World War does seem to have been a cause for the November promises and the establishment of the Commission of Inquiry. It created a mentality in the Netherlands Indies that made it easier for the Governor-General to make important policy decisions without consulting the Minister of Colonies. And it caused the events in Germany and the Netherlands in November 1918 that seem to have triggered the November promises and the establishment of the Commission of Inquiry. It should however be added that - as far as can be judged from the findings in this article - the First World War probably did not cause long-term changes in the relation between the Minister of Colonies and the Governor-General or in the system of constitutional law for the Netherlands Indies. The relation between the two offices returned to normal soon after the end of the First World War. And the report of the Commission of Inquiry did not become the foundation of the new system of constitutional law for the Netherlands Indies that was constituted in 1926.
109. Handelingen (1918-1919), above n. 60, at 2086.

110. Handelingen van de Eerste Kamer der Staten-Generaal (1918-1919), at 523. The 'substance of the matter' concerned the impossibility of an immediate introduction of responsible government in the Netherlands Indies. 